\title{
The Great Deluge and Its Coming
}

We were tangled together and carried roughly by the vicious waters, thrown about, buffeted cruelly

in the racing surge. We were a snarl of bald pates, bellies and spines with their multiple links,

a bolus, hairy bodies, snouts of fur, woolly all wound together, appendages, scaly appendages, fingers, hooves, claws, a clamor of sputterings, groans, and screeches tumbling over and over, each of us surfacing

momentarily, taking air from the sky, then submerged again, tossed, undone, entwined anew.

Two spider monkeys, dripping and wheezing, scrambled over my head for a place on top.

A hoary marmot

grabbed my ankle, slipped, caught a scrabble of branches drifting by carrying a rooster and corn snake.

A weasel-like

creature curled around my neck, jumped to the grizzled back of a warthog thrashing in the wake. What was it clawing and clutching at my shoulder?

Once, in the flooding mayhem, I came face-to-face with a blue-faced mandrill

First published in Wayfare (Penguin, 2008). 
and his fear-whitened eyes. Once a spotted bat grasped my collar, hung there until I was hit by a wave

and wrenched away clinging upside

down to a mule braying its harsh treble.

For a distance a dog, a dingo, held on

at my waist. I circled her mangy head

by her teeth clamped to the belt

with one arm, clung with the other

to the bulk of a musk ox

pitching past

in the swell. Seeds and nuts and the roots

of tundra grasses were matted in his long

hanging fur, among which roots crouched numerous mice harboring nits and fleas

and wingless flies.

We were mewing

and choking, spitting

and barking in our plight, the bundle

of us in a jumble, struggling, shifting constantly, losing hold

in white water, breaking apart,

carried away, found again. We were

knocked and shaken, buffeted against rocks,

engulfed flailing,

swung into shore by the current and jerked out

to mid-torrent again by the same.

Direction was destiny.

But were those really white wings spread wide,

gliding silently over us

all the way in the tumult?

Or was it simply a deeper heaven of moonlit clouds calm 
in a certain prophecy

that hovered above us through the night?

Or was it the ultimate stillness of the dependable void

that kept us comforted

until we were brought, finally floating

slowly together, almost sleeping,

into a growing light burning and blinding

like the conflagration of dawn over an open sea? 